\title{
Rates of spontaneous hybridization and hybrid recruitment in co-existing exotic and native mature larch populations
}

\author{
Patrick G. Meirmans • Marie-Claude Gros-Louis • \\ Manuel Lamothe • Martin Perron • Jean Bousquet • \\ Nathalie Isabel
}

Received: 25 October 2013 / Revised: 10 March 2014 / Accepted: 1 April 2014 / Published online: 18 April 2014

(C) The Author(s) 2014. This article is published with open access at Springerlink.com

\begin{abstract}
Exotic larch (Larix decidua Mill., Larix kaempferi (Lamb.) Carr. and Larix sibirica Ledeb.) and their hybrids have been introduced into Canada to test adaptation and growth for reforestation purposes. For tree breeding operations, provenance trials and seed orchards of exotic larches and their hybrids have been established in arboreta adjacent to natural forest stands of the indigenous species Larix laricina (Du Roi) K. Koch. This proximity offers an opportunity to measure spontaneous hybridization and the recruitment of hybrids. Using a combination of two chloroplast and three mitochondrial DNA markers, we estimated the rate of spontaneous hybridization taking place between native (L. laricina) and exotic (L. decidua, L. kaempferi, L. sibirica) species of larch in two arboreta. More than 5,000 seeds and 1,000 recruits from the two experimental sites were
\end{abstract}

Communicated by Y. Tsumura

Electronic supplementary material The online version of this article (doi:10.1007/s11295-014-0735-z) contains supplementary material, which is available to authorized users.

P. G. Meirmans $\cdot$ M.-C. Gros-Louis $\cdot$ M. Lamothe $\cdot$ N. Isabel $(\bowtie)$

Natural Resources Canada, Canadian Forest Service,

Laurentian Forestry Centre, 1055 du PEPS, Stn. Sainte-Foy,

P.O. box 10380, Québec, QC, Canada G1V 4C7

e-mail: nisabel@rncan.gc.ca

P. G. Meirmans

Institute for Biodiversity and Ecosystem Dynamics, University of Amsterdam, P.O. box 94248, 1090GE Amsterdam, The Netherlands

M.-C. Gros-Louis · J. Bousquet • N. Isabel

Canada Research Chair in Forest and Environmental Genomics, Forest Research Centre and Institute for Systems and Integrative Biology, Université Laval, Québec G1V 0A6, QC, Canada

\section{Perron}

Ministère des Ressources naturelles Québec,

Direction de la recherche forestière, 2700 rue Einstein, Québec

G1P 3W8, QC, Canada sampled and genetically identified. The occurrence of spontaneous hybridization between L. laricina and the exotics was found both in seeds and from recruits freely established near the plantations. A low hybridization rate (3\% or less) was observed among the seeds of L. laricina maternal trees. Spontaneous native-exotic hybrids were also observed to establish and survive in the environment under the current climatic conditions at a similarly low rate. However, a much higher and variable rate of establishment was observed for recruits with exotic components (up to $34.6 \%$ at one site). These results indicate that the spontaneous hybridization and the recruitment of hybrid and exotic recruits do occur and should be taken into consideration in the management and establishment of plantations of fast-growing species with exotic components.

Keywords Larix laricina $\cdot$ Exotic larch $\cdot$ Genetic identification $\cdot$ Spontaneous hybridization · Offspring establishment

\section{Introduction}

The introduction of plants with novel traits (PNTs) has raised concerns about the possibility of gene flow from plantations of non-native species into natural populations of wild relatives. These concerns involve not only genetically modified organisms but also the introduction of exotic species for agricultural, horticultural, or forestry purposes (Stewart et al. 2003; Chapman and Burke 2006; Laikre et al. 2010). Gene flow from PNTs into natural populations may result in the permanent introgression and fixation of non-native genomic regions in the genomes of native species (Kwit et al. 2011; Ghosh et al. 2012), which could modify ecological competence, negatively impact associated biological communities and lead to unforeseen economic costs (Ellstrand et al. 2013). 
Spontaneous hybridization has been documented in many agriculturally important species and natural populations of related species (Bartsch et al. 1999; Ellstrand et al. 1999). However, in most crop species, the process of domestication has led to significant genetic and morphological divergence between the crop and its wild progenitor, creating pre- and post-zygotic barriers to hybridization (Ellstrand et al. 1999). In contrast, forest trees that are used for plantations, such as larch (Larix Mill.) or poplar (Populus L.), are largely undomesticated and often show weak reproductive barriers between species (Zsuffa 1973; Pâques et al. 2006). This means that imported exotic species used for plantations may have an increased likelihood of hybridizing with wild populations (Acheré et al. 2004; Meirmans et al. 2010; Zahra et al. 2010; DiFazio et al. 2012).

Substantial progress has been made to quantify the rate of spontaneous hybridization between crop species and natural populations (Talbot et al. 2012; Ellstrand et al. 2013). However, introgression of non-native gene regions does not only depend on the hybridization rate. The formation of hybrids is merely the first step in a multi-step process lasting over many generations (Perron and Bousquet 1997; Wilkinson et al. 2003; Chapman and Burke 2006; Meirmans et al. 2009). Therefore, it becomes imperative to examine what happens after hybridization occurs and assess whether the produced hybrid seeds are viable and capable of freely establishing in the natural environment (Thompson et al. 2010; Hoban et al. 2012; Talbot et al. 2012; Roe et al. a, b in press).

Larix (larches, Pinaceae) is a small genus comprising ten species that are distributed across the northern hemisphere (Semerikov and Lascoux 1999; Wei and Wang 2003). Larches are widely used in forestry for pulp and paper, laminated veneer lumber, interior flooring, house frames, railroad ties, decking, and other exterior applications. Several Eurasian species (Larix decidua Mill., Larix kaempferi (Lamb.) Carr., and Larix sibirica Ledeb.) and their hybrids have been introduced into North America for use in plantations to alleviate harvesting pressure on natural forests (Dumoulin 1999; Colas et al. 2008). As for other conifers, reproductive barriers between larch species are generally weak and hybrids are easily produced (Baltunis et al. 1998; Acheré et al. 2004; Colas et al. 2008; Moriguchi et al. 2008). Hybrid larches are widely used in forestry because of their faster growth, higher volume, and increased resistance to insects and diseases (Eko et al. 2004; Perron 2008; Pâques 2009). Given the weak reproductive barriers, there is the possibility that populations of native larch found in eastern Canada, such as tamaracks (Larix laricina (Du Roi) K. Koch), hybridize spontaneously with exotic Eurasian species within plantations. Several studies (Häcker and Bergmann 1991; Colas et al. 2008; Pâques 2009) have already looked at the production of hybrid seeds in mixed plantations of $L$. decidua and L. kaempferi. However, little is known about spontaneous hybridization between these
Eurasian larches and native L. laricina, and whether hybrid seeds are viable and capable of establishing. In Populus, positive cases of spontaneous hybridization between exotic and native species and establishment of hybrid seedlings in the environment have been recently reported (Talbot et al. 2012; Roe et al. a, b in press).

In this study, we use a combination of paternally inherited chloroplast DNA (cpDNA) markers and maternally inherited mitochondrial DNA (mtDNA) markers to study spontaneous hybridization and establishment of hybrids between native (L. laricina) and exotic (L. decidua, L. kaempferi, L. sibirica) species of larch. We sampled and genotyped seeds and recruits of different age classes from two sites over a period of 4 years to address the following questions: (1) Does spontaneous hybridization occur between L. laricina and exotic larch species? (2) Does the hybridization rate vary over years and between sites? (3) Are hybrid seeds capable of germinating and establishing in the natural environment? and (4) Does the frequency of hybrids among the seeds match the frequency among the naturally established recruits?

\section{Materials and methods}

\section{Plant materials}

Plant tissue was collected in two arboreta established $700 \mathrm{~km}$ apart in the province of Quebec (eastern Canada) by the ministère des Ressources naturelles Québec. Each arboretum contained a mixture of hardwood and coniferous species, including native (L. laricina) and exotic larch species (L. decidua, L. kaempferi, and L. sibirica), as well as their hybrids (L. decidua $\times$ L. kaempferi) (Tables 1, S1). All larch plantations contained within these arboreta were sexually mature; at the time, this study was conducted, plantations in these two arboreta were the only sexually mature larch plantations available in eastern Canada that contained both L. laricina and many exotic species. The first arboretum is located near Saint-Elzéar-de-Bonaventure (hereafter named Bonaventure; Fig. 1, top). This site is surrounded by natural forests dominated by spruce (Picea spp.). We selected two larch plantations ( 0.7 ha) out of the eight established ( 9.9 ha) in this arboretum because they were composed of L. laricina and exotics (Table S1, plantations A and B). All together, these eight Larix plantations consisted of 3,418 planted Larix spp. trees comprising $6.1 \%$ L. laricina, $26.2 \%$ L. decidua, $56.3 \%$ L. kaempferi, $0.4 \%$ L. sibirica, and $11 \%$ hybrid larch (Tables 1, S1). The second arboretum, located in Sainte-Françoise-de-Lotbinière (hereafter named Lotbinière; Fig. 1, bottom), was surrounded by agricultural land, and contained a wide range of trees distributed in 70 trials covering approximately 145 ha (Tables $1, \mathrm{~S} 1$ ). At this site, we selected one plantation dominated by mature 
Table 1 Location and climatic parameters of the Bonaventure and Lotbinière arboreta sites where the study was conducted and the Larix species composition of all Larix plantations established within each arboretum

\begin{tabular}{|c|c|c|}
\hline Parameter/site & Bonaventure & Lotbinière \\
\hline Latitude (N) & 48.180 & 46.487 \\
\hline Longitude (W) & 65.340 & 71.939 \\
\hline Altitude (m) & 240 & 85 \\
\hline Mean annual temperature $\left({ }^{\circ} \mathrm{C}\right)^{\mathrm{a}}$ & 2.6 & 3.9 \\
\hline Total annual precipitation $(\mathrm{mm})^{\mathrm{a}}$ & 1220 & 1228 \\
\hline Number of days $>0{ }^{\circ} \mathrm{C}^{\mathrm{a}}$ & 263 & 274 \\
\hline Dominant wind direction (April-May) ${ }^{\mathrm{b}}$ & $\mathrm{E}$ & $\mathrm{ENE} / \mathrm{ESE}$ \\
\hline Wind speed (km/h; April-May) ${ }^{\mathrm{b}}$ & 13 & 12 \\
\hline Number of Larix spp. trees planted & 3418 & 11407 \\
\hline Establishment of plantations & $1973-1980$ & $1974-1990$ \\
\hline Arboretum size (ha) & 38 & 145 \\
\hline Total larch plantation size (ha) & 9.9 & 15.9 \\
\hline \multicolumn{3}{|l|}{ Total species composition (\%) } \\
\hline L. laricina $(\mathrm{L})$ & 6.1 & 19.0 \\
\hline L. decidua (D) & 26.2 & 44.0 \\
\hline L. kaempferi $(\mathrm{K})$ & 56.3 & 15.8 \\
\hline L. sibirica $(\mathrm{S})$ & 0.4 & 0.2 \\
\hline L. decidua $\times$ L. kaempferi $(\mathrm{H})$ & 11.0 & 21.0 \\
\hline
\end{tabular}

${ }^{a}$ Climate average (1971-2000)

${ }^{\mathrm{b}}$ Wind average (2001-2005)

L. laricina (3.9 ha) out of the 13 Larix plantations (15.9 ha) established within the arboretum (Table S1, plantation G). Together, the 13 plantations consisted of 11,407 planted Larix spp. trees and were composed of $19 \%$ L. laricina, $44 \%$ L. decidua, $15.8 \%$ L. kaempferi, $0.2 \%$ L. sibirica, and $21 \%$ hybrid larch (Tables $1, \mathrm{~S} 1$ ). In almost all plantations, at both sites, the tree density was low (Table S1) as they were managed to maximize open-pollinated seed production.

At the two sites, we collected three different types of samples: (1) seeds from L. laricina trees that were planted (PL), (2) seeds from L. laricina growing outside the plantation considered to be a natural population (NP, present only in Bonaventure) and, (3) seedlings (recruits) from in and around the studied plantations (Fig. 1). To assess the year-to-year variation in hybridization rate, we sampled seeds in 2002, 2003, 2004, and 2005, though not every tree was sampled every year due to variations in flowering time and seed production. In eastern Canada, there is an almost perfect phenological overlap among the flowering periods of the species considered except for $L$. decidua, which flowers 5-7 days earlier than the other species (Stipanicic and Mercier 1990; M. Perron, pers. obs.). Regarding climate, the sampling years were normal and did not show temperature or precipitation extremes, when compared with the long-term climate
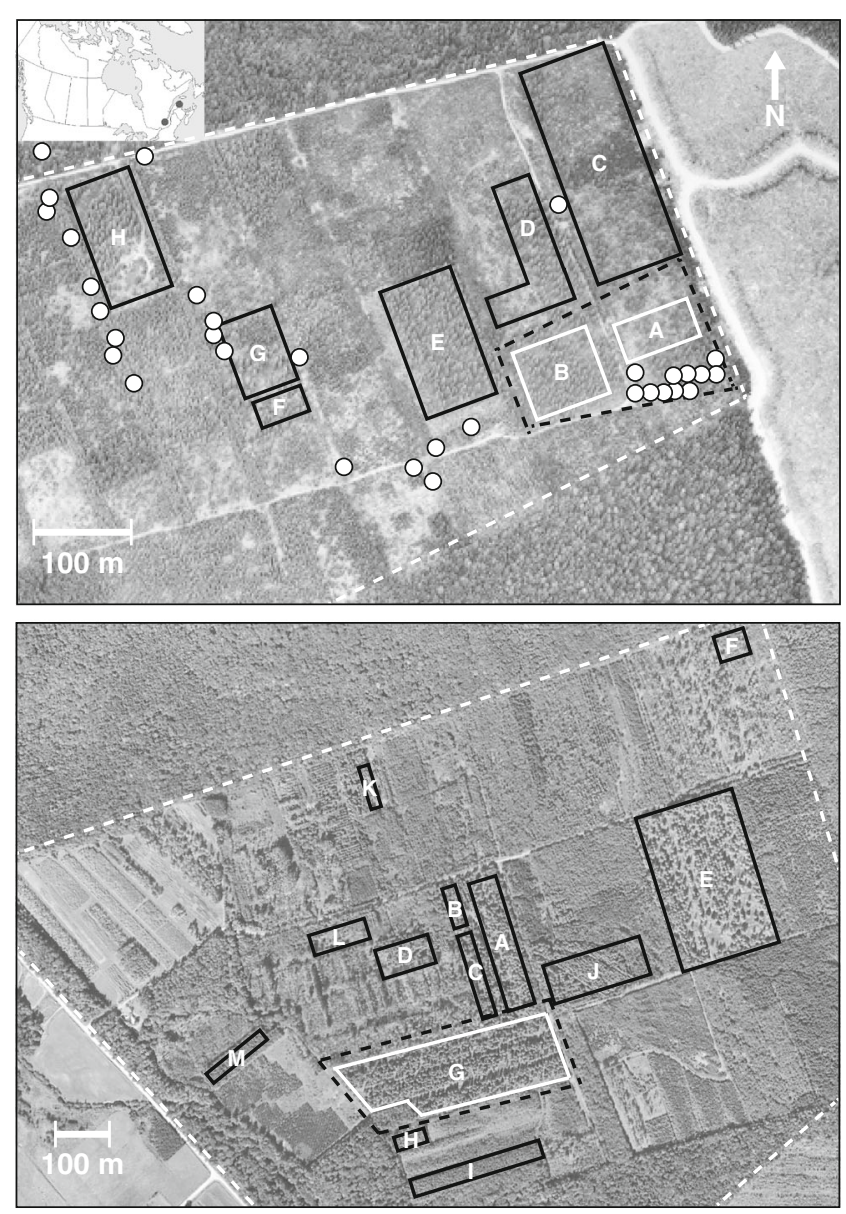

Fig. 1 Map of the two sampling sites: Bonaventure (top) and Lotbinière (bottom). Dotted white lines delineate the borders of the arboreta. White and dark lines delineate the borders of the studied plantations and the surrounding larch plantations, respectively. Dotted black lines show the areas of recruit collection. In Bonaventure (top), white circles indicate the relative position of mature natural $L$. laricina trees collected (not planted). Photos were provided by Géomathèque (ministère des Ressources naturelles Québec, geoboutique.mrnf.gouv.qc.ca)

normals. Seed production is generally low in larch, and the sampling years were no exception to this rule.

Cones ( $\sim 50$ cones per tree) were collected from 142 individual $L$. laricina located within the plantations (PL, $n=100)$ and outside the plantations (NP, $n=42$; Table 2). The total collection combined over the two sites and the 4 years was 194 samples, as some trees were sampled more than 1 year. This sampling yielded a total of 5,203 seeds for DNA extraction and genetic identification. From all sampled trees (PL and NP), needles were also collected to confirm the genetic identity of the maternal trees.

In addition to the seed samples, needles were sampled from 1,126 larch recruits (seedlings and saplings) from Bonaventure $(n=503)$ and Lotbinière $(n=623)$ that had established naturally inside and within $100 \mathrm{~m}$ of the plantation under study. To avoid sampling the same recruit twice, recruits with a stem under $1 \mathrm{~cm}$ diameter were cut while those over 
Table 2 Total number of Larix laricina maternal trees sampled and year-to-year paternal genotype contributions observed among seeds collected from planted (PL) trees at the Bonaventure and Lotbinière sites or natural (NP) trees at Bonaventure

\begin{tabular}{|c|c|c|c|c|c|c|c|c|}
\hline \multirow[t]{2}{*}{ Site } & \multirow[t]{2}{*}{ Year } & \multirow{2}{*}{$\begin{array}{l}\text { Number of } \\
\text { trees sampled }\end{array}$} & \multirow{2}{*}{$\begin{array}{l}\text { Number of } \\
\text { seeds genotyped }\end{array}$} & \multicolumn{5}{|c|}{ Paternal genotype contribution to seed (\%) } \\
\hline & & & & L. laricina & L. decidua & L. kaempferi & L. sibirica & Total exotic \\
\hline \multicolumn{9}{|c|}{ Bonaventure } \\
\hline \multirow[t]{4}{*}{ PL } & 2002 & 21 & 464 & $455(98.1)$ & $4(0.9)$ & $5(1.1)$ & $0(0.0)$ & $9(1.9)$ \\
\hline & 2004 & 35 & 1,128 & $1,088(96.5)$ & $31(2.7)$ & $9(0.8)$ & $0(0.0)$ & $40(3.5)$ \\
\hline & Total & 56 & 1,592 & $1,543(96.9)$ & $35(2.2)$ & $14(0.9)$ & $0(0.0)$ & $49(3.1)$ \\
\hline & Unique $^{\mathrm{a}}$ & 51 & & & & & & \\
\hline \multirow[t]{5}{*}{ NP } & 2002 & 14 & 317 & $306(96.5)$ & $7(2.2)$ & $4(1.3)$ & $0(0.0)$ & $11(3.5)$ \\
\hline & 2004 & 19 & 408 & $402(98.5)$ & $5(1.2)$ & $1(0.2)$ & $0(0.0)$ & $6(1.5)$ \\
\hline & 2005 & 18 & 338 & $320(94.7)$ & $10(3.0)$ & $8(2.4)$ & $0(0.0)$ & $18(5.3)$ \\
\hline & Total & 51 & 1,063 & $1,028(96.7)$ & $22(2.1)$ & $13(1.2)$ & $0(0.0)$ & $35(3.3)$ \\
\hline & Unique $^{\mathrm{a}}$ & 42 & & & & & & \\
\hline \multicolumn{9}{|c|}{ Lotbinière } \\
\hline \multirow[t]{5}{*}{ PL } & 2003 & 31 & 989 & 972 (98.2) & $8(0.8)$ & $9(1.0)$ & $0(0.0)$ & $17(1.7)$ \\
\hline & 2004 & 28 & 394 & 389 (98.7) & $2(0.5)$ & $3(0.8)$ & $0(0.0)$ & $5(1.3)$ \\
\hline & 2005 & 28 & 1,165 & $1,163(99.8)$ & $1(0.1)$ & $1(0.1)$ & $0(0.0)$ & $2(0.2)$ \\
\hline & Total & 87 & 2,548 & $2,524(99.0)$ & $11(0.4)$ & $13(0.5)$ & $0(0.0)$ & $24(0.9)$ \\
\hline & Unique $^{\mathrm{a}}$ & 49 & & & & & & \\
\hline
\end{tabular}

${ }^{a}$ This category represents the number of unique standing individual trees that were sampled over the course of this study

$1 \mathrm{~cm}$ diameter were labelled. All sampled recruits were less than 7 years old, and the great majority were less than 3 years old; therefore, they were not yet sexually mature. This means that our estimates of gene flow are not influenced by the presence of any sexually mature hybrid recruits.

\section{DNA extraction}

After collection, needles were frozen at $-20{ }^{\circ} \mathrm{C}$ prior to DNA extraction, for which we used the Qiagen DNeasy 96 Plant Kit (Mississauga, ON) according to the manufacturer's instructions. Cones were stored at $25{ }^{\circ} \mathrm{C}$ for 8 weeks to allow the scales to open in order to extract seeds. Only a small fraction of the seeds contained an embryo. Since seeds filled with an embryo are likely to be heavier than empty ones, the seeds were sorted according to weight before analysis, and only the heaviest fraction was retained. The retained seeds were dissected and the zygotic embryos were used for DNA extraction with the Qiagen MagAttract 96 DNA Plant Core Kit (Mississauga, ON) according to the manufacturer's instructions.

\section{Genotyping}

Our selection of genetic markers took advantage of the biparental organellar inheritance in larch where, as for most conifer species, chloroplast DNA (cpDNA) is paternally inherited while mitochondrial DNA (mtDNA) is maternally inherited (Neale et al. 1989). We used a combination of species-specific cpDNA and mtDNA markers to test for the presence of first-generation hybrids between the four larch species (Gros-Louis et al. 2005). We genotyped the needle samples from the recruits and the maternal trees using a combination of three mtDNA markers and two cpDNA markers to determine the genetic identity of these individuals. We screened seeds using just the two cpDNA markers as we were only interested in the paternal contribution given that we had previously genotyped the corresponding maternal trees (in almost all cases L. laricina) as described above.

\section{Mitochondrial DNA markers}

We used three mtDNA markers to identify the maternal inheritance: F-13 (Scheepers et al. 2000), matR-intron1 (Qiu et al. 1999), and nad5-intron1 (Jaramillo-Correa et al. 2003). F-13 is a SCAR (sequence characterized amplified region) marker that distinguishes $L$. decidua from the other three species. $M a t R$-intron1, when digested with the restriction enzyme Tsp509I, distinguishes L. laricina from the other three species. Nad5-intron1, when digested with HaeII, distinguishes L. sibirica from the other three species.

PCR reactions for F-13 were conducted using the protocol described by Acheré et al. (2004) and modified by Gros-Louis et al. (2005). A total volume of $30 \mu \mathrm{L}$ was used, containing 4 
to $40 \mathrm{ng}$ of genomic DNA, $1 \times$ reaction buffer, $1.25 \mathrm{mM}$ of $\mathrm{MgCl} 2, \mu \mathrm{M}$ of each dNTP (Amersham Pharmacia, Baie d'Urfé, QC), $0.25 \mu \mathrm{M}$ of each primer and 1.0 U of Platinum Taq DNA polymerase (Invitrogen, Burlington, ON). PCR amplifications were carried out on a Pelthier Thermal Cycler PTC200 (MJ Research, Waltham, MA), using the following program: one denaturation step of $3 \mathrm{~min}$ at $94^{\circ} \mathrm{C}$, followed by 35 cycles of $1 \mathrm{~min}$ at $94{ }^{\circ} \mathrm{C}$, s at $55^{\circ} \mathrm{C}$, and $3 \mathrm{~min}$ at $72{ }^{\circ} \mathrm{C}$, followed by a final extension of $10 \mathrm{~min}$ at $72{ }^{\circ} \mathrm{C}$. PCR products were separated into a $1.7 \%$ standard $1 \times$ Trisacetate-EDTA (TAE) agarose gel, stained in ethidium bromide, and visualized under UV light.

PCR reactions for matR and nad5 were conducted in a multiplex reaction using the following protocol (JaramilloCorrea et al. 2003). A total volume of $30 \mu \mathrm{L}$ was used containing 4 to $40 \mathrm{ng}$ of genomic DNA, $1 \times$ reaction buffer, $1.5 \mathrm{mM}$ of $\mathrm{MgCl} 2,200 \mu \mathrm{M}$ of each dNTP, $0.2 \mu \mathrm{M}$ of each primer, and 1.0 U of Platinum Taq DNA polymerase. Amplifications were performed using a Pelthier Thermal Cycler PTC200 programmed with one denaturation step of 2 min at $94{ }^{\circ} \mathrm{C}$, followed by 35 cycles of $30 \mathrm{~s}$ at $94{ }^{\circ} \mathrm{C}, 30 \mathrm{~s}$ at $60{ }^{\circ} \mathrm{C}$, and $1 \mathrm{~min}$ at $72{ }^{\circ} \mathrm{C}$, followed by a final extension of $10 \mathrm{~min}$ at $72{ }^{\circ} \mathrm{C}$. Digestion with Tsp509I and HaeII (New England Biolabs, Whitby, ON) was performed first with Tsp509I for $2 \mathrm{~h}$ at $65^{\circ} \mathrm{C}$ in a total volume of $10 \mu \mathrm{L}$ using $5 \mu \mathrm{L}$ of the PCR products, $1 \times$ reaction buffer, and $3 \mathrm{U}$ of restriction enzyme. Then, the temperature was decreased to $37{ }^{\circ} \mathrm{C}$ for $10 \mathrm{~min}$ before adding the HaeII enzyme solution prepared in a total volume of $2 \mu \mathrm{L}$ using $1 \times$ reaction buffer, 3 $\mathrm{U}$ of restriction enzyme and $1 \times \mathrm{BSA}$. Digestion with HaeII was performed for four more hours at $37{ }^{\circ} \mathrm{C}$. These PCRdigestion combinations (matR-Tsp509I, nad5-HaeII) could also be done separately. Digested PCR products were separated as described above.

\section{Chloroplast DNA markers}

For the sampled recruits, we used two cpDNA markers to identify paternal species: the $\operatorname{trn} L-\operatorname{trn} F$ intergenic spacer (Taberlet et al. 1991) and the fragment LL of the $r b c L$ gene (Acheré et al. 2004). Digesting trnL-trnF with the restriction enzyme EcoRV distinguishes L. laricina from the other three species, and digesting trnL-trnF with Bsp119I distinguishes $L$. sibirica from the other three species. Digesting $r b c L$ with the restriction enzyme TaqI distinguishes L. laricina and L. kaempferi from L. decidua and L. sibirica (Gros-Louis et al. 2005).

PCR reactions for trnL-trnF were conducted in a total volume of $30 \mu \mathrm{L}$ composed of $5 \mu \mathrm{L}$ of DNA template (4 to $40 \mathrm{ng}), 1 \times$ reaction buffer, $1.5 \mathrm{mM}$ of $\mathrm{MgCl} 2,200 \mu \mathrm{M}$ of each dNTP, $0.2 \mu \mathrm{M}$ of each primer, and $0.5 \mathrm{U}$ of Platinum Taq DNA polymerase. PCR amplifications were carried out on a PTC200 Thermal Cycler (MJ Research), using the following program: one denaturation step of $3 \mathrm{~min}$ at $94^{\circ} \mathrm{C}$, followed by 35 cycles of $1 \mathrm{~min}$ at $94^{\circ} \mathrm{C}, 1 \mathrm{~min}$ at $56^{\circ} \mathrm{C}$, and $1 \mathrm{~min}, 20 \mathrm{~s}$ at $72{ }^{\circ} \mathrm{C}$, followed by a final extension of $10 \mathrm{~min}$ at $72{ }^{\circ} \mathrm{C}$. Digestion with EcoRV (New England Biolabs) and Bsp119I (Fermentas, Ottawa, ON) was performed for $4 \mathrm{~h}$ at $37^{\circ} \mathrm{C}$ in a total volume of $10 \mu \mathrm{L}$ using $5 \mu \mathrm{L}$ of the PCR products, $1 \times$ reaction buffer, $1 \times \mathrm{BSA}$, and $3 \mathrm{U}$ of restriction enzyme. PCR reactions for $r b c L$ were conducted following the protocol for the F-13 protocol described above. Digestion of $r b c L$ with TaqI (New England Biolabs) was performed for $2 \mathrm{~h}$ at $65^{\circ} \mathrm{C}$ in a total volume of $20 \mu \mathrm{L}$ using $5 \mu \mathrm{L}$ of the PCR products, $1 \times$ reaction buffer, $1 \times \mathrm{BSA}$, and $3 \mathrm{U}$ of restriction enzyme.

Data analysis

Differences in hybridization rates were calculated using a series of exact tests, using the "fisher.test" command in the statistical framework R v. 2.14.0 (R Core Team 2012).

\section{Results}

Seeds collected from planted trees (PL) at Bonaventure and Lotbinière

We found a low level of spontaneous hybridization between the native and exotic larches based on seeds collected from planted trees (PL) within the plantations at Bonaventure and Lotbinière (Table 2, Fig. 1 white lines). Combined over the 4 sampling years, a total of 4,140 seeds obtained from L. laricina mothers were genotyped; 1,592 from Bonaventure and 2,548 from Lotbinière. Of these, 73 seeds $(1.8 \%)$ were sired by exotics: $46(1.1 \%)$ were sired by L. decidua and $27(0.7 \%)$ by L. kaempferi. The hybrids were distributed relatively evenly over the sampled maternal plants; there was no mother tree that produced a statistically significant disproportionate number of hybrid offspring. When comparing the two sites, there was a significant difference (Fisher's exact test $P=8.2 \times 10^{-7}$ ) in their hybridization rate with a much higher rate at Bonaventure $(3.1 \%)$ than at Lotbinière $(0.9 \%)$.

In Bonaventure, more seeds were sired by L. decidua (35; $2.2 \%$ ) than by L. kaempferi (14; $0.9 \%$ ). Furthermore, we did not detect any hybrid seeds sired by $L$. sibirica despite its presence in the surrounding plantations (Tables 1, S1). A weakly significant difference was found between the 2 sampling years (Fisher's exact test $P=0.047$ ), with a slightly higher hybridization rate in 2004. In Lotbinière, seeds were primarily sired by L. laricina $(99.0 \%)$, with a small number of seeds pollinated by L. kaempferi $(13 ; 0.5 \%)$ and L. decidua (11; $0.4 \%$ ); again, none of the produced seeds was sired by L. sibirica. For Lotbinière, there was a strongly significant 
variation in spontaneous hybridization rate among the 3 sampling years (Fisher's exact test $P=8.9 \times 10^{-4}$ ).

Seeds collected from natural trees (NP) at the Bonaventure site

From the 42 pure L. laricina maternal trees that were sampled from the native stand at Bonaventure, we sampled 1,063 seeds over 3 years and detected a total of 35 seeds $(3.3 \%)$ that were sired by the exotic species. This frequency was not significantly different from the frequency of hybrid seeds $(3.1 \%)$ detected in L. laricina individuals from the adjacent plantations at the same site (Fisher's exact test $P=0.70$ ). As was the case in the adjacent plantation, more seeds sampled from the natural stand were sired by L. decidua $(22 ; 2.1 \%)$ than by L. kaempferi $(13 ; 1.2 \%)$ and none was sired by $L$. sibirica (Table 2). When looking at the 3 years of seed collection from L. laricina from the natural population (NP), there was a small but significant difference in the hybridization rate among years (Fisher's exact test $P=0.034$ ). There was a strong individual effect: of the 14 natural $L$. laricina trees sampled in 2002 , a single tree was responsible for $63.6 \%$ of the exotic seeds produced. In 2004 and 2005, out of the 37 natural trees sampled, only three contributed $42 \%$ of the hybrid seeds.

In addition to the stand of native larch at Bonaventure, we genotyped seeds from four naturally established exotic larches: two pure L. kaempferi, one L. laricina $\times$ L. decidua hybrid, and one L. sibirica $\times$ L. decidua hybrid (data not shown). All 81 seeds that were genotyped from the two L. kaempferi trees were sired by L. kaempferi. Results from the L. laricina $\times$ L. decidua hybrid show that L. kaempferi sired 15 seeds $(41.7 \%)$, with the remaining seeds sired by $L$. decidua. The $L$. sibirica $\times L$. decidua hybrid produced very few viable seeds in the year it was sampled, but the two viable seeds that were produced were both sired by $L$. decidua.

\section{Sampled recruits}

The Larix plantations established at the Bonaventure and Lotbinière sites produced a genetically diverse mixture of larch species and hybrids among the sampled recruits. At both sites, the majority of sampled recruits were identified as pure L. laricina, although there were striking differences between the two sites (Table 3, Fig. 2). In Bonaventure, only $64.4 \%$ of the harvested recruits were pure L. laricina as revealed by the maternal (mtDNA) and paternal (cpDNA) markers, the rest being recruits with exotic components. Moreover, a large number of pure exotic recruits were also found: $1.0 \%$ from L. decidua, $13.5 \%$ from $L$. kaempferi, and $0.2 \%$ from L. sibirica. In Lotbinière, a higher percentage of recruits $(94.4 \%)$ were pure $L$. laricina with only $5.7 \%$ of hybrid recruits. As for pure exotic recruits, only $1.3 \%$ were $L$. kaempferi and no pure $L$. decidua or $L$. sibirica recruits were found at this site. It is of interest to note that no recruits were found from exotic maternal trees (L. decidua, L. kaempferi, or L. sibirica) that would have been sired by L. laricina.

Hybrid recruits bearing only exotic components were also detected, although their relative frequency varied between
Table 3 The number of recruits (\%) sampled around the plantations at both the Bonaventure and Lotbinière sites and presented by parental genotype class. For every sampled recruit, the genotype of both its parents (maternal in rows and paternal in columns) was determined. Percentages are based on the total number of recruits sampled.

\begin{tabular}{|c|c|c|c|c|c|c|}
\hline \multirow[t]{2}{*}{ Maternal genotype } & \multirow[t]{2}{*}{ Number of recruits } & \multicolumn{5}{|c|}{ Paternal genotype } \\
\hline & & L. laricina & L. decidua (D) & L. kaempferi $(\mathrm{K})$ & $\mathrm{D}$ or $\mathrm{K}^{\mathrm{a}}$ & L.sibirica \\
\hline \multicolumn{7}{|l|}{ Bonaventure } \\
\hline L. laricina & 329 & $324(64.4)$ & $2(0.4)$ & $3(0.6)$ & $0(0.0)$ & $0(0.0)$ \\
\hline L. decidua & 27 & $0(0.0)$ & $5(1.0)$ & $16(3.2)$ & $6(1.2)$ & $0(0.0)$ \\
\hline L. kaempferi & 81 & $0(0.0)$ & $7(1.3)$ & $68(13.5)$ & $6(1.2)$ & $0(0.0)$ \\
\hline L. sibirica & 66 & $0(0.0)$ & $23(4.6)$ & $26(5.2)$ & $16(3.2)$ & $1(0.2)$ \\
\hline Total & 503 & $324(64.4)$ & $37(7.4)$ & $113(22.5)$ & $28(5.6)$ & $1(0.2)$ \\
\hline \multicolumn{7}{|l|}{ Lotbinière } \\
\hline L. laricina & 605 & $588(94.4)$ & $9(1.4)$ & $8(1.3)$ & $0(0.0)$ & $0(0.0)$ \\
\hline L. decidua & 0 & $0(0.0)$ & $0(0.0)$ & $0(0.0)$ & $0(0.0)$ & $0(0.0)$ \\
\hline L. kaempferi & 17 & $0(0.0)$ & $9(1.4)$ & $8(1.3)$ & $0(0.0)$ & $0(0.0)$ \\
\hline L. sibirica & 1 & $0(0.0)$ & $1(0.2)$ & $0(0.0)$ & $0(0.0)$ & $0(0.0)$ \\
\hline Total & 623 & $588(94.4)$ & $19(3.1)$ & $16(2.6)$ & $0(0.0)$ & $0(0.0)$ \\
\hline
\end{tabular}

${ }^{\text {a }}$ At Bonaventure, the paternal contribution (whether it was L. decidua or L. kaempferi) could not be determined entirely for 28 individuals 
Fig. 2 Observed frequency (\%) of spontaneous interspecific hybrids found within seed lots collected from planted (PL) and natural (NP) L. laricina trees and from recruits having a L. laricina mother at both the Lotbinière and Bonaventure sites. The results were combined over the 4-year period (2002-2005)
4.0

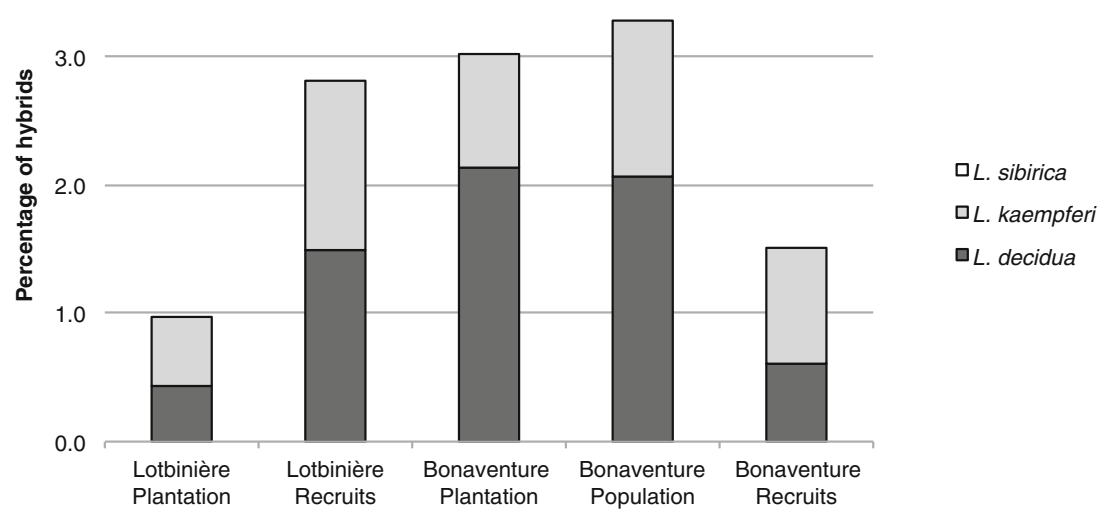

sites (Table 3). In Bonaventure, we detected a large number of hybrid recruits with $L$. sibirica maternal trees $(n=65,12.9 \%)$ that were sired by L. decidua or L. kaempferi fathers (Table 3 ). The remainder of the fully exotic hybrids at Bonaventure were from crosses between $L$. decidua $\times$ L. kaempferi $(n=16$, $3.2 \%)$ or its reciprocal $(n=7,1.3 \%)$. It should be noted that these percentages are lower bonds given that for some of the offspring, it was not possible to distinguish between L. decidua and L. kaempferi due to failed PCR-reactions for $r b c L$. The results from Bonaventure contrast with those obtained in Lotbinière where only nine L. kaempferi $\times$ $L$. decidua recruits and single $L$. sibirica $\times L$. decidua recruit were detected.

For comparison purposes with the results of spontaneous hybridization from seed collections, it is important to draw attention to the genetic composition of the recruits from L. laricina maternal trees (Fig. 2). In Bonaventure, of the 329 recruits with L. laricina mothers, 324 (98.5\%) were sired by a $L$. laricina as shown above, and five $(1.5 \%)$ hybrids were sired by some exotics. In Lotbinière, we detected 605 recruits with a L. laricina mother of which $588(97.2 \%)$ were pure L. laricina; among the 17 (2.8\%) hybrids, there were approximately as many individuals sired by $L$. decidua fathers as by L. kaempferi ones.

\section{Discussion}

Hybrids in seeds from L. laricina

In this study, we have shown that $L$. laricina has relatively low levels of spontaneous hybridization with adjacent sexually mature exotic trees, even when growing amidst individuals from other species and at low tree density to promote seed production. Combined overall 5,203 genotyped seeds, we found only 108 hybrids $(2.1 \%)$. The percentages that we found match those observed for poplar in the Canadian prairies where a low percentage of hybrid seeds was produced by native poplars growing close to shelterbelts consisting of exotic hybrids (Talbot et al. 2012). In poplar, the percentage of hybrids observed in native stands was also found to match the percentage of hybrids in the seeds (Talbot et al. 2012).

While low rates of spontaneous hybridization were observed in the seeds of L. laricina (mother trees) sampled, the proportion of recruits harboring exotic components with a mother L. laricina was about three times higher for the Lotbinière site (Fig. 2, Table 3). The contrasting patterns between the two sites are difficult to explain by only considering compatibility differences between species. The difference is most likely explained by the abundance of $L$. laricina in the sampled plantations or its surroundings relative to the abundance of trees with exotic components, and their effect on the saturation of the local pollen cloud around the mother trees sampled (Meirmans et al. 2010). In Lotbinière, more than $99 \%$ of the trees in the sampled plantation were L. laricina (Table S1, plantation G), and this is reflected in the lower hybridization rate compared with that observed in Bonaventure, where the sampled plantations consisted more of a mixture of species (Table S1, plantations A and B). Though there were many exotic larches in the other plantations at Lotbinière, these may have had a lesser effect on the local pollen cloud of the plantation where mother larches were sampled. Furthermore, the pollen grains of larch do not have any special adaptations, such as large air bags, to promote long-distance dispersal; as a result, pollen is usually dispersed only over relatively short distances of up to $300 \mathrm{~m}$ (Matras and Pâques 2008).

There were also significant differences in hybridization rate among years that could also be explained by differences in the genetic composition of the pollen cloud. Most notably in Bonaventure, the hybridization rate was much higher in 2004 than in 2002. One possible reason is that during the establishment of the arboretum, five shelterbelts composed of more than $200 \mathrm{~L}$. laricina each were planted between the plantations. In late fall of 2002, these shelterbelts were cut, thereby reducing the proportion of L. laricina pollen 
producers within the orchard from 18 to $6 \%$. In Lotbinière, the differences among years were less pronounced, though there was a slightly lower hybridization rate in 2005 than in 2003 and 2004. These differences might also be accounted for by year-to-year differences in the abundance of pollen and pollen release dates of the different species, as related to differences in spring temperatures.

These trends are reminiscent of those reported in poplars where the abundance of natural indigenous components in the vicinity of the plantations of exotics was inversely correlated with the rate of hybrid seeds in trees of the native species, suggesting a key role of the genetic composition of the local pollen cloud (Meirmans et al. 2010).

In general, the relative contributions of the different exotic components in the hybrid seeds were not consistent with the proportion of the exotic species present within the arboretum, which might reflect compatibility differences. At Bonaventure, L. kaempferi was the most abundant species present in the plantation (56.3\% of the planted trees) but was responsible for less than a third of the hybrid seeds. In contrast, $L$. decidua was present at only $26.2 \%$ in the plantation but sired the majority of hybrid seeds even though it flowers slightly earlier than the other species (Stipanicic and Mercier 1990; M. Perron, pers. obs.). On the other hand, at Lotbinière, L. kaempferi sired slightly more hybrid seeds than $L$. decidua, even though $L$. decidua was more abundant in the plantation. Only about $1 \%$ of the planted trees belonged to L. sibirica, and in line with this, none of the hybrid seeds were sired by this species.

At both the Bonaventure and Lotbinière arboreta, a significant proportion of the planted trees were $L$. decidua $\times$ L. kaempferi hybrids (11 and $21 \%$, respectively). Since the genotyping markers used could not distinguish between hybrid and pure pollen donors of this complex, the relative contribution of each of these two exotics could not be identified clearly. However, since these planted hybrids are derived from two exotic species, such a lack of identification of the exact exotic pollen donor should not affect our estimates of spontaneous hybridization between exotic and native components, as well as rates of hybrid recruit establishment.

\section{Hybrids in recruits}

The formation of hybrid seeds is only the first of several steps towards introgression (Perron and Bousquet 1997; Wilkinson et al. 2003; Chapman and Burke 2006; Meirmans et al. 2009, Thompson et al. 2010). The produced hybrids also need the ability to germinate and establish themselves in the environment (Roe et al.a, b in press). Therefore, we also looked at the presence of hybrids among the recruits that were naturally occurring in and around the studied plantations. At both the Bonaventure and Lotbinière sites, the recruits were mostly found in the vicinity of the plantations at spots where there was an open space, beside fern-covered areas or along the paths. The larch regeneration decreased drastically with distance from the plantation boundaries, as we did not find any recruits in the natural forest outside the arboretum at the Bonaventure site, or outside the L. laricina plantations at the Lotbinière site. When looking only at recruits with $L$. laricina maternal composition, the frequencies of hybrid recruits $(2.3 \%)$ were quite similar to the proportions detected in the seeds sampled from $L$. laricina trees $(2.1 \%)$. These results indicate that there is no immediate post-zygotic barrier between the species. However, since less than $10 \%$ of the collected recruits were saplings ( $\geq 3$ years old), we can only draw this conclusion about the first few years of growth after germination. Postzygotic effects that play on longer time scales may still be important, but a longer-term study would be necessary to identify them. This type of long-term study has been performed around 23 plantations of Norway spruce planted as an exotic species in Québec, where no regeneration was found more than $20 \mathrm{~m}$ from the boundaries of the plantations (Mottet et al. 2010).

We also observed a relatively large number of recruits that were fully exotic at the Bonaventure site: these were either pure species or hybrids. A notable observation was the large presence of $L$. sibirica, which was found in $13 \%$ of the recruits in Bonaventure, despite taking up only $1 \%$ of the trees in the plantation. However, it is possible that these recruits were the progeny of the naturally established exotic hybrid $($ L. sibirica $\times$ L. decidua) we found. In Lotbinière, the presence of the sampled mother trees within a large plantation of indigenous $L$. laricina clearly reduced the frequency of exotics among the recruits. It is of interest to note that for both sites, no recruits were found from exotic mothers (L. decidua, L. kaempferi, or L. sibirica) that were sired by L. laricina (Table 3). These results are in agreement with the genotypes of the seeds collected from female larch bearing an exotic component. It is also interesting to note that about $80 \%$ of the observed hybrid recruits were between the Eurasian exotic species, indicating that these seem to hybridize more easily with each other than with L. laricina. This pattern reflects the phylogenetic relationships among the species, since the Eurasian species are more closely related to each other than to L. laricina (LePage and Basinger 1991; Semerikov and Lascoux 1999, 2003; Semerikov et al. 2003; Gros-Louis et al. 2005). It confirms the results of Pâques (1992) who was unable to successfully cross L. laricina and $L$. decidua and found low seed set in crosses between L. laricina and L. kaempferi.

While the rate of spontaneous interspecific hybridization is likely determined in part by the phylogenetic distance between species, an important prezygotic barrier may be the flowering phenology of the species and especially a lack of overlap among species. Furthermore, given that larches often exhibit protandry (with the male flowers opening before the female 
flowers), the direction of hybridization may be highly skewed when there is only partial overlap in flowering time between species. Such a lack of overlap in flowering time was the reason why Pâques (1992) was unable to obtain any successful crosses between L. laricina and L. decidua. However, in eastern Canada, the flowering time of the studied species is mostly overlapping, with $L$. decidua flowering slightly earlier than the other three species (Stipanicic and Mercier 1990; M. Perron, pers. obs.). Still, there may have been differences between the species in the amount of pollen produced, which may have influenced our results. Unfortunately, obtaining reliable phenological data is difficult since it is timeconsuming with multi-year assessments, and accurately measuring the pollen production is difficult with mature trees of $>20 \mathrm{~m}$ height. Therefore, we did not combine our genetic analysis with an assessment of the phenology.

Given that overall rates of spontaneous hybridization between L. laricina and exotic larches were low, and that both sampling sites were located in the center of the distribution of L. laricina, there may have been a buffering effect of the local pollen cloud caused not only by the relatively high abundance of L. laricina in the plantations analyzed or their vicinity but also from the regional pollen cloud. The pollen cloud may have reduced further the level of spontaneous hybridization given that non-conspecific pollen and may be less successful in fertilizing ovules than conspecific pollen. Such a buffering effect was noticed before in a study on introgression from plantations of exotic poplar into natural populations of Populus balsamifera where the frequency of hybrid offspring produced by $P$. balsamifera trees was six times higher at the range margin where the local and regional populations were small relative to the center of the distribution where the population was very large (Meirmans et al. 2010).

\section{Practical implications and conclusion}

Even though hybrid larches are widely used in forestry (Acheré et al. 2004; Eko et al. 2004; Pâques 2009; Perron 2011), our results show that spontaneous hybridization is relatively rare in the centre of the distribution, even in plantations with a mixture of species. Our results indicate that while introgression of exotic components into L. laricina may not be a concern, the presence of exotic species and their hybrids may pose a potential risk. Our work has focused mainly on hybrid seeds produced by L. laricina as a pathway to introgression, but we have shown that introgression from introduced species into the native $L$. laricina can also occur through the spontaneous establishment of exotic hybrid or pure exotic species produced in plantations. Therefore, both the spontaneous hybridization with native species and the establishment of the exotics present possible invasion risks.
However, we also observed that the recruits were mainly limited to the plantations and their immediate surroundings so that removal could proceed at harvesting. This limited invasiveness is likely a consequence of the shade-intolerant nature of larches so they may have difficulties in establishing themselves within natural larch stands. Also, though larches share some properties with trees that have indeed become invasive (Dodet and Collet 2012), we are not aware of any signs that L. decidua, L. kaempferi, and L. sibirica have become invasive or even naturalized in Canada after more than a century of use in forestry. However, to further elaborate on this, the growth of the recruits needs to be followed over the long term in order to evaluate their fitness and spread of exotic genes. It is imperative that such long-term establishment be quantified when exotic larches are to be used on a large scale for reforestation, in order to address concerns about their potential to invade natural forests.

Acknowledgments We would like to thank Gaston Lapointe and François Caron (ministère des Ressources naturelles du Québec) who helped with the collection of larch material at both arboreta. This study would not have been possible without the help of Amélie Claveau, Karyne Plante, Patricia Sylvestre, Joannie Normandin, and Roxane Boivin (Natural Resources Canada) with DNA extractions and molecular marker validation. We also would like to thank Amanda Roe and Pamela Cheers (Natural Resources Canada) and anonymous reviewers for their useful comments on the earlier version of this manuscript. This study was funded through grants from the Canadian Regulatory System for Biotechnology to NI and Fonds québécois pour la recherche sur la nature et les technologies (FQRNT) to JB.

Data Archiving Statement Detailed genotype results for recruits, parents (RecruitsAndParents.txt), and seeds (Seeds.txt) are given in supplementary materials.

Open AccessThis article is distributed under the terms of the Creative Commons Attribution License which permits any use, distribution, and reproduction in any medium, provided the original author(s) and the source are credited.

\section{References}

Acheré V, Rampant PF, Pâques LE, Prat D (2004) Chloroplast and mitochondrial molecular tests identify European $\times$ Japanese larch hybrids. Theor Appl Genet 108:1643-1649

Baltunis BS, Greenwood MS, Eysteinsson T (1998) Hybrid vigor in Larix: growth of intra- and interspecific hybrids of Larix decidua, L. laricina, and L. kaempferi after 5-years. Silvae Genet 47:288-293

Bartsch D, Lehnen M, Clegg J, Pohl-Orf M, Schuphan I, Ellstrand NC (1999) Impact of gene flow from cultivated beet on genetic diversity of wild sea beet populations. Mol Ecol 8:1733-1741

Chapman MA, Burke JM (2006) Letting the gene out of the bottle: the population genetics of genetically modified crops. New Phytol 170: 429-443 
Colas F, Perron M, Tousignant D, Parent C, Pelletier M, Lemay P (2008) A novel approach for the operational production of hybrid larch seeds under northern climatic conditions. For Chron 84:95104

DiFazio S, Leonardi S, Slavov G, Garman S, Adams W, Strauss S (2012) Gene flow and simulation of transgene dispersal from hybrid poplar plantations. New Phytol 193:903-915

Dodet M, Collet C (2012) When should exotic forest plantation tree species be considered as an invasive threat and how should we treat them? Biol Invasions 14:1765-1778

Dumoulin F (1999) Le reboisement, un outil pour augmenter la productivité. In, Ressources naturelles Canada, Service canadien des forêts. L'amélioration génétique en foresterie, où en sommesnous? Actes du colloque sur l'amélioration génétique au Québec, Rivière-du-Loup, Québec, Canada, pp 25-30

Eko PM, Larsson-Stern M, Albrektson A (2004) Growth and yield of hybrid larch (Larix $\times$ eurolepis A. Henry) in southern Sweden. Scand J For Res 19:320-328

Ellstrand NC, Prentice HC, Hancock JF (1999) Gene flow and introgression from domesticated plants into their wild relatives. Annu Rev Ecol Syst 30:539-563

Ellstrand NC, Meirmans PG, Rong J, Bartsch D, Ghosh A, de Jong TJ, Haccou P, Lu BR, Snow A, Stewart CN, Strasburg JL, van Tienderen PH, Vrieling K, Hooftman DAP (2013) Introgression of crop alleles into wild and weedy populations. Annu Rev Ecol Syst 44:325-345

Ghosh A, Meirmans PG, Haccou P (2012) Quantifying introgression risk with realistic population genetics. Proc R Soc B-Biol Sci 279:47474754

Gros-Louis M-C, Bousquet J, Pâques L, Isabel N (2005) Speciesdiagnostic markers in Larix spp. based on RAPDs and nuclear, cpDNA, and mtDNA gene sequences, and their phylogenetic implications. Tree Genet Genomes 1:50-63

Häcker M, Bergmann F (1991) The proportion of hybrids in seed from a seed orchard composed of two larch species (L. europaea and L. leptolepis). Ann For Sci 48:631-640

Hoban SM, McCleary TS, Schlarbaum SE, Anagnostakis SL, Romero-Severson J (2012) Human-impacted landscapes facilitate hybridization between a native and an introduced tree. Evol Appl 5:720-731

Jaramillo-Correa JP, Bousquet J, Beaulieu J, Isabel N, Perron M, Bouillé M (2003) Cross-species amplification of mitochondrial DNA sequence-tagged-site markers in conifers, the nature of polymorphism and variation within and among species in Picea. Theor Appl Genet 106:1353-1367

Kwit C, Moon HS, Warwick S, Stewart CN (2011) Transgene introgression in crop relatives, molecular evidence and mitigation strategies. Trends Biotechnol 29:284-293

Laikre L, Schwartz MK, Waples RS, Ryman N (2010) Compromising genetic diversity in the wild, unmonitored large-scale release of plants and animals. Trends Ecol Evol 25:520-529

LePage BA, Basinger JF (1991) A new species of Larix (Pinaceae) from the early Tertiary of Axel Heiberg Island, Arctic Canada. Rev Palaeobot Palynol 70:89-111

Matras J, Pâques LE (2008) EUFORGEN Technical Guidelines for genetic conservation and use for European larch (Larix decidua). Bioversity International, Rome, Italy, $6 \mathrm{p}$

Meirmans PG, Bousquet J, Isabel N (2009) A metapopulation model for the introgression from genetically modified plants into their wild relatives. Evol Appl 2:160-171

Meirmans PG, Lamothe M, Gros-Louis M-C, Khasa D, Périnet P, Bousquet J, Isabel N (2010) Complex patterns of hybridization between exotic and native North American poplar species. Am J Bot 97:1688-1697

Mottet M-J, Prégent G, Perron M, DeBlois J, Lambert M-C (2010) Régénération naturelle de l'épinette de Norvège au Québec : aucun signe d'envahissement. Note de recherche forestière 135. Ministère des Ressources naturelles et de la Faune, Direction de la recherche forestière. $12 p$

Moriguchi Y, Kita K, Uchiyama K, Kuromaru M, Tsumura Y (2008) Enhanced hybridization rates in a Larix gmelinii var. japonica $\times$ L. kaempferi interspecific seed orchard with a single maternal clone revealed by cytoplasmic DNA markers. Tree Genet Genomes 4: $637-645$

Neale DB, Marshall KA, Sederoff RR (1989) Chloroplast and mitochondrial DNA are paternally inherited in Sequoia sempervirens D. Don Endl. Proc Natl Acad Sci U S A 86:9347-9349

Pâques L (1992) Performance of vegetatively propagated Larix decidua, L kaempferi and L laricina hybrids. Ann Sci For 49:63-74

Pâques L (2009) Growth rhythm parameters as components of hybrid vigour in young seedlings of hybrid larch (Larix decidua $\times$ L. kaempferi). Silvae Genet 58:42-53

Pâques L, Philippe G, Prat D (2006) Identification of European and Japanese larch and their interspecific hybrid with morphological markers: application to young seedlings. Silvae Genet 55:123134

Perron M (2008) A strategy for the second breeding cycle of Larix $\times$ marschlinsii in Québec, Canada including experiments to guide interspecific tree breeding programme. Silvae Genet 57:282-291

Perron M (2011) Le mélèze hybride du Québec, performant et racé. Avis de recherche forestière 37 . Ministère des Ressources naturelles et de la Faune, Direction de la recherche forestière. $2 \mathrm{p}$

Perron M, Bousquet J (1997) Natural hybridization between black spruce and red spruce. Mol Ecol 6:725-734

Qiu YL, Lee J, Bernasconi-Quadroni F, Soltis DE, Soltis PS, Zanis M, Zimmer EA, Chen Z, Savolainen V, Chase MW (1999) The earliest angiosperms, evidence from mitochondrial, plastid and nuclear genomes. Nature 402:404-407

R Core Team (2012) R: A language and environment for statistical computing. R Foundation for Statistical Computing, Vienna, Austria. http://www.R-project.org

Roe AD, MacQuarrie CJK, Gros-Louis M-C, Simpson DJ, Lamarche J, Beardmore T, Thompson SL, Tanguay P, Isabel N. (a) Fitness dynamics within a poplar hybrid zone: I. Prezygotic and postzygotic barriers impacting a native poplar hybrid stand. Ecol Evol, doi:10. 1002/ece3.1029

Roe A, MacQuarrie CJK, Gros-Louis M-C, Simpson DJ, Lamarche J, Beardmore T, Thompson SL, Tanguay P, Isabel N. (b) Fitness dynamics within a poplar hybrid zone: II. Impact of exotic sex on native poplars in an urban jungle. Ecol Evol, in press

Scheepers D, Eloy MC, Briquet M (2000) Identification of larch species (Larix decidua, Larix kaempferi and Larix $\times$ eurolepis) and estimation of hybrid fraction in seed lots by RAPD fingerprints. Theor Appl Genet 100:71-74

Semerikov VL, Lascoux M (1999) Genetic relationship among Eurasian and American Larix species based on allozymes. Heredity 83:62-70

Semerikov VL, Lascoux M (2003) Nuclear and cytoplasmic variation within and between Eurasian Larix (Pinaceae) species. Am J Bot 90: 1113-1123

Semerikov VL, Zhang HQ, Sun M, Lascoux M (2003) Conflicting phylogenies of Larix (Pinaceae) based on cytoplasmic and nuclear DNA. Mol Phylogenet Evol 27:173-184

Stewart CN, Halfhill MD, Warwick SI (2003) Transgene introgression from genetically modified crops to their wild relatives. Nat Rev Genet 5:806-813

Stipanicic A, Mercier S (1990) Étude phénologique de l'anthère de quelques espèces forestières en relation avec les degrés-jours et le nombre de jours. Note de recherche forestière no 49. Ministère des Forêts du Québec, Direction de la recherche. $10 \mathrm{p}$

Taberlet P, Gielly L, Pautou G, Bouvet J (1991) Universal primers for amplification of three non-coding regions of chloroplast DNA. Plant Mol Biol 17:1105-1109 
Talbot P, Schroeder WR, Bousquet J, Isabel N (2012) When exotic poplars and native Populus balsamifera L. meet on the Canadian Prairies: Spontaneous hybridization and establishment of interspecific hybrids. For Ecol Manag 285:142-152

Thompson S, Lamothe M, Meirmans PG, Perinet P, Isabel N (2010) Repeated unidirectional introgression towards Populus balsamifera in contact zones of exotic and native poplars. Mol Ecol 19:132-145

Wei XX, Wang XQ (2003) Phylogenetic split of Larix, evidence from paternally inherited cpDNA trnT-trnF region. Plant Syst Evol 239:67-77
Wilkinson MJ, Elliott LJ, Allainguillaume J, Shaw MW, Norris C, Welters R, Alexander M, Sweet J, Mason DC (2003) Hybridization between Brassica napus and B-rapa on a national scale in the United Kingdom. Science 302:457-459

Zahra S, Cici H, Van Acker RC (2010) Gene flow in Prunus species in the context of novel trait risk assessment. Environ Biosafety Res 9:7585

Zsuffa L (1973) A summary review of interspecific breeding in the genus Populus. Proc Can Tree Improv Assoc 14:107-123 